\title{
The Application of DEA Method in Evaluating Credit Risk of Companies ${ }^{1}$
}

Submitted: November $12^{\text {th }}, 2010$

Accepted: December $3^{\text {rd }}, 2010$

\section{Summary}

The subject of the present article is a new procedure forecasting credit risk of companies in Polish economy environment. What favors the suggested approach is the fact that in Poland, unlike in western countries, DEA method has not yet been implemented in order to assess credit risk that companies face. The research described in the article has been conducted on the basis of comparison of suggested DEA method with currently used procedures, namely point method, discriminative analysis and linear regression. Considering the research, it can be concluded that DEA method facilitates forecasting financial problems, including bankruptcy of companies in Polish economic conditions, and its effectiveness is comparable or even greater than approaches implemented so far.

\section{Introduction}

Credit risk is inextricably link with every bank's activity. It is one of the basic types of credit risk. It is understood mainly as the risk of default by a borrower with remaining interest rates and commissions. Competent credit risk management plays a major role in the process of bank administration. All operations undertaken by a bank, especially those involving loans are meant to reduce that risk. Using credit-scoring methods is believed to be one of the most accurate solutions, facilitating the process of credit risk management. It is worth mentioning that the procedure of credit - scoring has become more significant

\footnotetext{
${ }^{*}$ Dr, adiunkt, Politechnika Rzeszowska.

${ }^{1}$ The article presents results of research conducted within research project \# H02B 01530 financed with educational sources.
} 
since Basel Committee on Banking Supervision published guidelines of New Capital Contract, according to which credit - scoring is one of the possible tools of assessing credit risk within internal ratings (Iwanicz-Drozdowska, 2005: 130,150). The procedure of using DEA method for credit-scoring suggested in the article may prove an effective tool in solving the problems of credit risk assessment in Polish banks.

\section{Implementing DEA method in credit risk management}

DEA method was first introduced in 1978 by American economists Charnes, Cooper and Rhodes. Relying on productivity concept, formulated by G. Debreu (1951) and M.J. Farrel (1957), which defined effectiveness measure as quotient of singular effect and singular set-up, they used it for a multidimensional situation in which there was more than one set-up as well as more than one effect. Using DEA method, effectiveness of an object is calculated in relation to other objects from particular group. Effective objects within particular group make so-called effectiveness curve. Effectiveness of remaining objects is calculated in relation to the curve defined through solving the issue of linear programming (using DEA method).

Methodology of credit risk assessment with the use of DEA method suggested below was prepared on the basis of literature studies (Emel, Oral, Reisman \& Yolalan, 2003: 103123; Simak, 2000: 1-189; Gospodarowicz, 2004: 119-129) as well as the author's own research (Feruś, 2006a: 44-59; Feruś, 2006b: 245-253; Feruś, 2006c: 263-269; Feruś 2007a: 225-233; Feruś, 2007b: 144-154; Feruś, 2008a: 196-215; Feruś 2008b: 153-160;

Fig. 1. Suggested method of assessing credit risk of companies, using DEA method

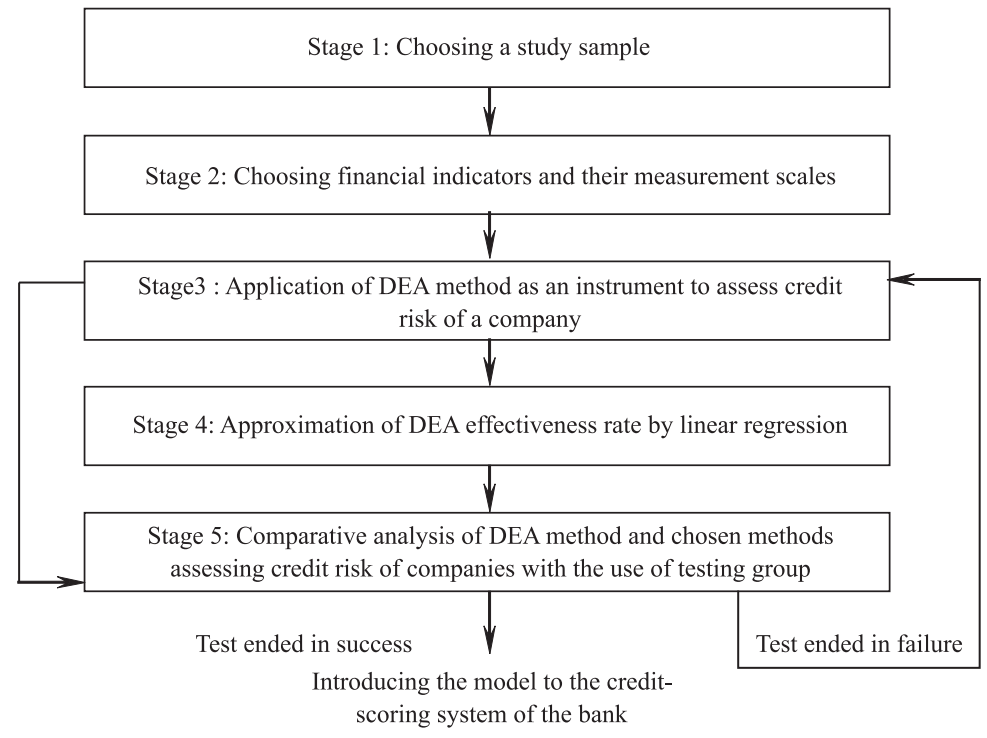

Source: Own study. 
Feruś, 2008c: 109-118; Feruś, 2009: 221-231). It consists of five stages, as presented in figure 1.

\section{Stage 1: Choosing a study sample}

The base of a study was statistical matter containing information provided by a bank on 100 construction companies that obtained a credit loan in the years 2001-2003. This study included the status of credit repayment history ${ }^{2}$.

\section{Stage 2: Choosing financial indicators and their measurement scales}

The analysis was conducted for one year period as well as two years before considering the firms as bankrupt. The study used 22 financial indicators. Next, based on correlation assumption 6 indicators were chosen (table 1) that did not contain any information provided by other financial indicators from this study, but at the same time were good representative indicators that were not chosen for diagnosis ${ }^{3}$.

Table1. Financial indicators used in the study

\begin{tabular}{|c|l|}
\hline $\begin{array}{c}\text { Indicator's } \\
\text { symbol }\end{array}$ & \multicolumn{1}{c|}{ Indicator's formula } \\
\hline$X_{1}$ & $\begin{array}{l}\text { Net profit indicator }=\text { (financial result*100) / (profit from sales and equals + other operation } \\
\text { profits + financial profits) }\end{array}$ \\
\hline$X_{2}$ & Asset return indicator (ROA net) $=$ (financial result*100) / total of assets \\
\hline$X_{3}$ & $\begin{array}{l}\text { Individual assets return indicator (ROE net) }=\left(\text { net financial result* } 100^{*} 12 / \mathrm{n}\right) / \text { individual as- } \\
\text { sets }\end{array}$ \\
\hline$X_{4}$ & Current liquid indicator $=$ revolving capital / short term debts \\
\hline$X_{5}$ & $\begin{array}{l}\text { Daily return indicator }=\text { (total of return*\#of days) / (profit from sales and equals+ other } \\
\text { operation profits }+ \text { financial profits) }\end{array}$ \\
\hline$X_{6}$ & General debt indicator $=$ (general debts*100) / total return \\
\hline
\end{tabular}

Source: Own study.

\section{Stage 3: Application of DEA method as an instrument to assess credit risk of a company}

A crucial problem in this stage is the choice of the right set ups and effects used in firms' component. Assignment of the individual financial indicators to groups of set ups and effects depends mainly on problem format. Often the scripts on the studied object indicate five basic ways to define set up and effect: producer concept, financial agent concept, financial asset concept, summarized value concept and user expense concept. The solution of a given problem based on DEA method depends on choosing the right DEA model. To classify DEA model two criteria must be present simultaneously: type of effect scale and orientation of the model. The first criterion defines what theories were applied

\footnotetext{
${ }^{2}$ Statistical matter contained 50 solvable firms and 50 firms with delinquency risk

${ }^{3}$ Chosen indicators were weakly correlated with each other and strongly correlated with fluctuating alignment.
} 
to effect scale in the model (variable (VRS), constant (CRS) or not rising (NIRS)). The second factor demonstrates whether set ups are minimized or effects are maximized. Depending on the choice of the model orientation, what can be calculated is either the technical effectiveness of set up or technical effectiveness oriented on solution or so called undirected models.

Based on thorough literature study (Emel, Oral, Reisman \& Yolalan, 2003: 108-121; Simak, 2000: 43-100; Gospodarowicz, 2004: 123-129), credit inspectors' interview and personal experiences (Feruś, 2006a: 44-59; Feruś, 2006b: 245-253; Feruś, 2006c: 263269; Feruś, 2007a: 225-233; Feruś, 2007b: 144-154; Feruś, 2008a: 196-215; Feruś, 2008b: 153-160; Feruś, 2008c: 109-118; Feruś, 2009: 221-231] in that aspect, set up and effect classifications were created ${ }^{4}$ :

- set ups: $X_{5}$ and $X_{6}$

- effects: $X_{1}, X_{2}, X_{3}$ and $X_{4}$

To calculate the technical effective indicator value of studied firms CCR (constant scale effect) model was used. This was directed toward set ups with search for minimal value of effectiveness indicator that will possibly reduce the amount of set up and result in equal effect of the study object. For this calculation optimal linear program EMS ${ }^{5}$ was used. The effectiveness indicator results for each firm in the study ranged from 0 to 1 . The value of effectiveness indicator equal to 1 demonstrates the firm being effective whereas, the effectiveness indicator value lower than 1 demonstrates the firm has an opportunity to improve the relations of set ups and effects - indicates effectiveness loss level.

In this part of the study research was also carried out aiming at finding the base point (cut off point) of effectiveness coefficient that will separate the solvent group of firms from the firms with the risk of delinquency.

A good concept, allowing for setting the right base point value, but also considering incorrect object classification, was a study of interdependency between the value of incorrect classification and the value of base point. In this approach, optimal base point regulates minimal entire cost of incorrect classification. Moreover, this concept permits multi variant analysis, the optimal base point change due to incorrect classification Type I or II. To show entire cost of incorrect classification the following formula was applied (Simak, 2000: 94-95):

$$
T C=i(p) \cdot C_{1}+j(p) \cdot C_{2}
$$

where: $C_{1}$ - loss indicator Type I error; $C_{2}-$ loss indictor Type II error; $i(p)$ - error quantity Type I; $j(p)$ - error quantity Type II.

For the purpose of this study, $C_{1}$ and $C_{2}$ is equal to 0,6 and 0,03 respectively.

For the above mentioned CCR model (constant scale effect) concentrated on set ups, effectiveness coefficient base value was verified for a year as well as two years before

\footnotetext{
${ }^{4}$ The author used numerous studies examining the model effectiveness. Present article gives the final model that proved to be the most effective in determining the firms' credit risk factor.

${ }^{5}$ Dortmund University website sources: http://wiso.unidortmund.de/LSFR/OR/scheel/ems
} 
Table 2. Evaluation of different methods effectiveness using 2001-2002 data*

\begin{tabular}{|c|c|c|c|c|c|c|c|c|}
\hline Method & \multicolumn{2}{|c|}{ MP } & \multicolumn{2}{c|}{ AD } & \multicolumn{2}{c|}{ RL } & \multicolumn{2}{c|}{ DEA } \\
\hline Base point & \multicolumn{2}{|c|}{-} & \multicolumn{2}{|c|}{$\mathbf{0}$} & \multicolumn{2}{|c|}{$\mathbf{0}$} & \multicolumn{2}{c|}{$\mathbf{0}$} \\
\hline \multirow{5}{*}{2001} & $S_{2}$ & $100 \%$ & $S_{2}$ & $96 \%$ & $S_{2}$ & $96 \%$ & $S_{2}$ & $90 \%$ \\
\cline { 2 - 9 } & $S_{1}$ & $58 \%$ & $S_{1}$ & $80 \%$ & $S_{1}$ & $80 \%$ & $S_{1}$ & $72 \%$ \\
\cline { 2 - 9 } & $S$ & $79 \%$ & $S$ & $88 \%$ & $S$ & $88 \%$ & $S$ & $81 \%$ \\
\hline \multirow{3}{*}{2002} & $S_{2}$ & $100 \%$ & $S_{2}$ & $90 \%$ & $S_{2}$ & $90 \%$ & $S_{2}$ & $80 \%$ \\
\cline { 2 - 9 } & $S_{1}$ & $70 \%$ & $S_{1}$ & $86 \%$ & $S_{1}$ & $86 \%$ & $S_{1}$ & $84 \%$ \\
\cline { 2 - 9 } & $S$ & $85 \%$ & $S$ & $88 \%$ & $S$ & $88 \%$ & $S$ & $82 \%$ \\
\hline
\end{tabular}

* $S_{2}$ - Type II Efficiency - determines what percentage of solvable firms was correctly classified $\left(S_{2}=\frac{P 2}{P 2+N P 2} * 100 \%\right.$; where $P 2$ - number of solvable firms classified as solvable group, $N P 2$ - number of solvable firms classified as delinquency risk group), $S_{1}$ - Type I Efficiency - determines what percentage of firms with delinquency risk was correctly classified $\left(S_{1}=\frac{P 1}{P 1+N P 1} * 100 \%\right.$; where $P 1$ - number of firms with risk of delinquency classified as delinquency risk group, $N P 1$ - number of firms with risk of delinquency classified as solvable, $S$ - General Classification of Efficiency - determines what percentage of all firms was

correctly classified with application of the $\left(S=\frac{P 1+P 2}{P 1+N P 1+P 2+N P 2} * 100 \%\right)$. The base point value in the discrimination analysis model and regressive linear model was calculated as average value from average of the groups.

Source: Own study.

delinquency below 0,40 . This indicates the 0,40 or lower rank implies a high risk of defaulting. Furthermore, 0,40 or higher rank implies a low risk of defaulting.

The DEA method classification effectiveness is illustrated in Table 2. In addition, the DEA method results (table 2) were compared with point method (MP) results as well as with regressive linear (RL) results. Using the same material, the author was able to complete a credible comparative analysis using statistical data.

Based on the classification results shown in Table 2 it could be concluded that effectiveness of I and II classification with the use of DEA method is similar to discriminating analysis and regressive linear regression.

\section{Stage 4: Approximation of DEA efficiency rate by linear regression}

The main purpose of this phase is an attempt at reducing the DEA method fallacy caused by a necessity of applying an optimal linear program for every study of a firm applying for a credit loan (Simak, 2000: 94-95). The suggested solution to this problem is the application of regressive linear function that allows for finding a correlation between the coefficient DEA method value and its effectiveness with defined set ups and effects. In this case, regressive linear function could be used as linear estimation of coefficient DEA method values without the need of extensive process of DEA method verification each time a new firm is applying for a credit. In other words, regressive linear function could be used while determining the studied firm's credit risk level without going through the first three phases (Emel, Oral, Reisman \& Yolalan, 2003: 108-115]. Accordingly, the regressive linear 
function was defined during the process of estimating the coefficient value of DEA method effectiveness. Past coefficient DEA method of effectiveness values through regressive linear function were treated as a dependent variable $Y$ (endogenous variable), and defined set up and effect were noted as an operand $X_{i}$ (exogenous variable). The regressive linear function research was conducted through Statistica 6.0 program. When rating the value of regressive linear function model the level of significance was established.

This is the final linear regression model formula:

$Y_{\text {DEA } 2001-2002}=\_0,0006 X_{5}+0,0010 X_{6}+0,0826 X_{1}+0,0126 X_{2}-0,0003 X_{3}+0,2831 X_{4}+0,0564$

Table 3. Selected properties of regressive linear function $Y_{D E A}$

\begin{tabular}{|l|c|c|c|c|c|c|}
\hline \multicolumn{7}{|c|}{$\boldsymbol{R}^{\mathbf{2}}=\mathbf{6 7 \%} \boldsymbol{F} \mathbf{( 6 / 9 3 )}=\mathbf{3 1 , 4 6}$} \\
\hline \multicolumn{1}{|c|}{ Variables } & $\mathbf{X}_{\mathbf{5}}$ & $\mathbf{X}_{\mathbf{6}}$ & $\mathbf{X}_{\mathbf{1}}$ & $\mathbf{X}_{\mathbf{2}}$ & $\mathbf{X}_{\mathbf{3}}$ & $\mathbf{X}_{\mathbf{4}}$ \\
\hline$t\left(a_{i}\right)$ & $-4,82$ & 2,32 & 3,64 & 2,62 & $-2,13$ & 6,57 \\
\hline Empirical level of essence $p$ & 0,0000 & 0,0227 & 0,0004 & 0,0102 & 0,0354 & 0,0000 \\
\hline
\end{tabular}

Source: Own study.

Table 4. Comparing the classification effectiveness of DEA method with regressive linear function $Y_{D E A}$

\begin{tabular}{|c|c|c|c|c|}
\hline \multirow{2}{*}{} & \multicolumn{4}{|c|}{ Base point = 0,40 } \\
\cline { 2 - 5 } & $\mathbf{2 0 0 2}$ & $\mathbf{2 0 0 1}$ & $\mathbf{2 0 0 2}$ & $\mathbf{2 0 0 1}$ \\
\cline { 2 - 5 } & $80 \%$ & $90 \%$ & $86 \%$ & $86 \%$ \\
\hline$S_{2}$ & $84 \%$ & $72 \%$ & $86 \%$ & $76 \%$ \\
\hline$S_{1}$ & $82 \%$ & $81 \%$ & $86 \%$ & $81 \%$ \\
\hline$S$ & & & & \multicolumn{2}{c|}{$Y_{\text {DEA }}$} \\
\hline
\end{tabular}

Source: Own study.

Summarizing the results of above study (Table 3 - test of essence: t-Student, F-Snedecora, determining coefficient $R^{2}$ ) one can recognize that the choice of dependent variables in the regressive linear function $Y_{\mathrm{DEA}}$ is accurate. Furthermore, all the regressive linear function $Y_{\text {DEA }}$ properties were statistically significant.

The efficient classification results in Table 4 in regressive linear function $Y$ DEA-20012002 do not differ considerably from the DEA method results shown in Stage 3 of this study, which means that equalization of the linear regression could be treated as linear approximation of the coefficient DEA effectiveness value.

\section{Stage 5: Comparative analysis of DEA method and chosen methods assessing credit risk of companies with the use of testing group}

To check and verify the accuracy and effectiveness of prognostic qualities of above studied models, the statistic matter (100 firms) was divided equally 1:1 in respect to two separate research samples: controlled and placebo group. The effectiveness rate of both groups' classification is presented in Table 5. 
Table 5. Comparing the effectiveness of various methods for the placebo sample group using 2001-2002 data

\begin{tabular}{|c|c|c|c|c|c|c|}
\hline Method & \multicolumn{2}{|c|}{ AD } & \multicolumn{2}{c|}{ RL } & \multicolumn{2}{c|}{ DEA } \\
\hline Base point & \multicolumn{2}{|c|}{$\mathbf{0}$} & \multicolumn{2}{|c|}{$\mathbf{0 , 5}$} & \multicolumn{2}{c|}{$\mathbf{0 , 5}$} \\
\hline \multirow{3}{*}{2001} & $S_{2}$ & $96 \%$ & $S_{2}$ & $96 \%$ & $S_{2}$ & $88 \%$ \\
\cline { 2 - 7 } & $S_{1}$ & $68 \%$ & $S_{1}$ & $68 \%$ & $S_{1}$ & $80 \%$ \\
\cline { 2 - 7 } & $S$ & $82 \%$ & & $82 \%$ & & $84 \%$ \\
\hline \multirow{3}{*}{2002} & $S_{2}$ & $88 \%$ & $S_{2}$ & $88 \%$ & $S_{2}$ & $84 \%$ \\
\cline { 2 - 7 } & $S_{1}$ & $80 \%$ & $S_{1}$ & $80 \%$ & $S_{1}$ & $96 \%$ \\
\cline { 2 - 7 } & $S$ & $84 \%$ & $S$ & $84 \%$ & $S$ & $84 \%$ \\
\hline
\end{tabular}

Source: Own study.

Based on above classification results in Table 5 it can be determined that DEA method has superior prognostic indicators. It best minimizes type I errors where classification effectiveness was higher than $12 \%$ two years before delinquency and higher than $16 \%$ one year before delinquency. However, general classification effectiveness of DEA method is similar to general classification for methods: discrimination and linear regression analysis.

\section{Conclusions}

Based on the analysis in this article it would be justified to say that a well reflected credit scoring model is reliable in differentiating potential high risk of default from low risk of default clients. Founded by the study, it can be concluded that DEA method correctly predicts possible financial difficulties including a company's bankruptcy risk in Polish economic situation. These results are comparable or even superior to other methods presently employed.

This study signifies the universal application of DEA method in analyzing large spectrum of credit risk uncertainty. It not only measures efficiency in respect to the use of financial risk indicators, but it facilitates accurate credit risk classification for corporations in credit application process.

This credit scoring method is very dynamic, very promising, and continually developing.

\section{References}

Emel A.B., Oral M., Reisman A., Yolalan R., A credit scoring approach for the commercial banking sector, Socio-Econoimc Planning Sciences 37, 2003.

Feruś A., Zastosowanie metody DEA do określania poziomu ryzyka kredytowego przedsiębiorstw, „Bank i Kredyt", 2006a nr 7.

Feruś A., Okrélanie poziomu ryzyka kredytowego przedsiębiorstw z wykorzystaniem metody DEA, [in:] Problemy zarzadzania finansami we wspótczesnych przedsiębiorstwach, Szczepankowski P. (ed.), VizjaPress\&IT, Warszawa 2006b. 
Feruś A., Szacowanie ryzyka kredytowego przedsiębiorstw z wykorzystaniem metody DEA, [in:] Finanse przedsiębiorstwa, Karpuś P. (ed.), Wydawnictwo Uniwersytetu Marii Curie-Skłodowskiej, Lublin 2006c.

Feruś A., Szacowanie ryzyka kredytowego przedsiębiorstw ze szczególnym uwzględnieniem metody DEA, [in:] Harmonizacja bankowości i ubezpieczeń w skali narodowej i europejskiej, Marcinkowska M., Wieteska S. (ed.), Difin, Warszawa 2007a.

Feruś A., Wykorzystanie metody DEA do oceny ryzyka kredytowego przedsiębiorstw w ramach credit-scoringu, [in:] Zarzqdzanie finansami firm - teoria i praktyka, Pluta W. (ed.), Prace Naukowe Akademii Ekonomicznej we Wrocławiu nr 1152, Wrocław 2007b.

Feruś A., УРАВЛІННЯ КРЕДИТНИМИ ИЗИКАМИ ІДРИСМСТВ ЗА ДООМОГОЮ МЕТОДУ DЕА - Zarzqdzanie ryzykiem kredytowym przedsiębiorstw z zastosowaniem metody DEA, [in:] АКТУАЛЬНІ РОБЛЕМИ УРАВЛІННЯ - Aktualne problemy zarzqdzania: Монографiя, tom 2, Запоріжжя-Жешув 2008а.

Feruś A., Zarzqdzanie ryzykiem kredytowym przedsiębiorstw z wykorzystaniem metody DEA w ramach credit-scoringu, [in:] Zarzq̨dzanie finansami firm - teoria i praktyka, Bernaś B. (ed.), Prace Naukowe Akademii Ekonomicznej we Wrocławiu nr 1200, Wrocław 2008b.

Feruś A., The DEA metod in managing the credit risk of companies [in:] "Ekonomika", 84/2008, Vilnius University, Vilnius 2008c.

Feruś A., Zarządzanie ryzykiem kredytowym przedsiębiorstw z wykorzystaniem metody DEA w ramach credit-scoringu, [in:] Zarzqdzanie finansami firm - teoria i praktyka, Bernaś B. (ed.), Prace Naukowe Akademii Ekonomicznej we Wrocławiu nr 48, Wrocław 2009.

Gospodarowicz A., Możliwości wykorzystania metody DEA do oceny ryzyka kredytowego w kontekście Nowej Umowy Kapitalowej, [in:] Przestrzenno-czasowe modelowanie i prognozowanie zjawisk gospodarczych, Zeliaś A. (ed.), Akademia Ekonomiczna w Krakowie, Kraków 2004.

Iwanicz-Drozdowska M., Zarzqdzanie finansowe bankiem, PWE, Warszawa 2005.

Simak P.C., Inverse and Negative DEA and their Application to Credit Risk Evaluation, Centre for Management of Technology and Enterpreneurship, Faculty of Applied Sciences and Engineering, University of Toronto, Toronto 2000.

\section{Zarządzanie ryzykiem kredytowym przedsiębiorstw z zastosowaniem metody DEA}

\section{Streszczenie}

Przedmiotem niniejszego artykutu jest zaproponowanie nowego postępowania prognozujacego ryzyko kredytowe przedsiębiorstw w polskich warunkach gospodarczych. Za podjęciem proponowanych badań przemawia fakt, iż $w$ Polsce $w$ przeciwieństwie do krajów zachodnich nie podejmowano prób zastosowania metody DEA do szacowania ryzyka kredytowego przedsiębiorstw. Badania byly prowadzone na zasadzie porównania proponowanej metody DEA z metodami obecnie stosowanymi ( $t j$. metoda punktowa, analiza dyskryminacyjna, regresja liniowa). Na podstawie przeprowadzonych badań można wnioskować, że metoda DEA umożliwia przewidywanie trudności finansowych, łacznie z zagrożeniem bankructwem przedsiębiorstw w polskich warunkach gospodarczych na poziomie porównywalnym lub nawet przewyższajacym dotychczas stosowane metody. 